\title{
Particle-associated bacterial dynamics in a tropical tidal plain (Zuari estuary, India)
}

\author{
Maria-Judith B. D. De Souza, Shanta Nair, P. A. Loka Bharathi*, D. Chandramohan \\ Biological Oceanography Division, National Institute of Oceanography, Dona Paula, 403-004 Goa, India
}

\begin{abstract}
The dynamics of particle-associated bacteria (PAB) in a tropical estuary, Zuari, in Goa on the west coast of India, was studied for a year from September 1997 to October 1998. Bacterial abundance, productivity and enzymatic activities were measured at a fixed station in the estuary. The study period covered pre-monsoon (February to May), southwest monsoon (June to September) and post-monsoon (October to January) seasons. Particulate organic carbon ranged from 0.5 to $17.5 \mathrm{mg} \mathrm{C}$ $\mathrm{l}^{-1}$. Particles of size range $>3$ to $<220 \mu \mathrm{m}$ were the most abundant, were rich in organic carbon $(\sim 60 \%)$, and formed $55 \%$ of the suspended load (ave. $\left.\sim 0.1 \mathrm{~g} \mathrm{l}^{-1}\right)$ in the estuary. PAB ranged from $8.8 \times 10^{7}$ to $3.9 \times 10^{10} \mathrm{l}^{-1}$ and the waters close to the sediment had a higher abundance than the surface waters. PAB varied seasonally and accounted for 20 to $80 \%$ of the total bacterial population. The mean rate of production as measured by ${ }^{3} \mathrm{H}$-thymidine incorporation was $70 \mu \mathrm{g} \mathrm{Cl}^{-1} \mathrm{~d}^{-1}$ in the surface and $35 \mu \mathrm{g} \mathrm{C}^{-1} \mathrm{~d}^{-1}$ in the bottom waters. Monthly production varied by 2 orders and was not coupled to abundance. However, high production during the monsoon was fuelled by allochthonous input of organic matter. No linear relationship was observed between biological parameters and other measured environmental parameters except for temperature, which showed a linear relationship with $\mathrm{PAB}$ and particle numbers. The bacterial carbon demand (BCD) at the station was higher than the primary production (PP) and was met by allochthonous input. Our study demonstrates that the PAB dynamics were determined by the availability of substrates and resuspension of sedimented materials.
\end{abstract}

KEY WORDS: Particle-associated bacteria $\cdot$ Biomass $\cdot$ Productivity $\cdot$ Tropical $\cdot$ Estuary

\section{INTRODUCTION}

Estuarine environments exhibit a wide variation in physical and chemical factors, both in space and time. One may expect differences in biota and the biotic dynamics in relation to morphology, catchments, allochthonous inputs and other chemical and physiological factors. Irrespective of the estuary, particles are known to be a major component of the system (Eisma 1993, Crump et al. 1999). They may be retained either in the estuary or transported to the adjoining coastal waters depending upon the magnitude of the riverine flow and the tide. Particles are formed of suspended organic and inorganic matter produced by biologically enhanced physical processes (Kiørboe et al. 1990). These fragile microscopic particles are composed of fecal pellets, decaying macrophytes and phytoplank- ton, mineral and detrital particles (Alldredge \& Silver 1988, Velmirov 1991). Bacteria that colonize such aggregates in estuaries form a significant fraction of the total bacterial population in contrast to the larger size aggregates of the open oceans (Bell \& Albright 1981, Iriberri et al. 1987, Zimmermann \& Kausch 1996, Zimmermann 1997, Grossart \& Simon 1998). It has been generally observed that the density of bacteria on particles is higher than that of free-living bacteria in the water (Caron et al. 1986, Caron 1987, MüllerNiklas et al. 1994, Turley \& Mackie 1994). Adsorbed material, availability of potential substrates, organic components of particles, and increased flux of nutrients are some of the reasons why particles form a favorable microenvironment for bacterial colonization (Fletcher 1991, Kirchman 1993). Particle-associated bacteria (PAB) also seem to contribute to the break- 
down of macroaggregates by mechanical disruption and direct consumption of the particulate material (Lochte 1991, Zimmermann \& Kausch 1996). Thus the estuary forms an important site for bacterial degradation of terrestrial and riverine organic matter associated with particles (Lee \& Wakeham 1988).

$\mathrm{PAB}$ are now recognized as an important component of the food web in the estuarine system (Crump et al. 1999) because they tend to be retained in the estuary either by sinking or re-suspension (Crump et al. 1998). In temperate estuaries, like that of the Columbia River in the northwestern USA, particleassociated/attached bacteria have been shown to account for $90 \%$ of the total bacterial production (Crump et al. 1998), and in the Elbe Estuary (Germany) they are $4 \times 10^{3}$ times more concentrated than the free-living bacteria (Zimmermann 1997). Thus, particles are not only a site for decomposition but also form an important component of the food web. The available studies on estuaries, however, do not allow a generalization of the parameters controlling bacterial dynamics, probably due to the high environmental variability of these ecosystems. For instance in the Gambia River, West Africa, the dominance of attached bacteria was related to high seston loads (Healey et al. 1988), while in turbid St. Lawrence Estuary, Canada, attached bacteria were found to play a minor role (Painchaud \& Therriault 1989). The absolute amount of bacteria and relative contribution by particle-associated bacteria are expected to vary among estuaries because of differences in organic matter quality and quantity. Thus a combination of intrinsic and extrinsic controlling factors may account for magnifying differences among the estuaries.

Very little work on PAB has been carried out in tropical estuaries except in a tidal creek of the Indus delta, Pakistan (Bano et al. 1997), in the Gambia River (Healey et al. 1988), and in the Ivory Coast (Ducklow \& Shiah 1993). No study has been made on an annual basis to understand the seasonal changes in $\mathrm{PAB}$ in a tropical estuary. At the study station in the Zuari estuary (Goa, India), seasonality is brought about by the southwest (SW) monsoon, which is accompanied by high influx of fresh water. There is a comparatively low run-off season during November to May as compared to the heavy run off period from June to October (Shetye et al. 1995). The quality, timing and characteristic of allochthonous loading may affect the system. Hence, a study on bacterial activities on particles is of immediate relevance. We do not know whether (1) this estuary forms an important energetic link between riverine and marine fronts like the temperate estuaries, or (2) wind-driven monsoons influence the particles and their associated bacteria.
The objective of our study was to describe how PAB in the Zuari estuary respond to physico-chemical and biological changes during an annual cycle. In this paper we (1) quantify the abundance of bacteria on particles in the water column and their contribution to the total microbial activity, and (2) bring out the importance of attached bacteria to the status of the estuary.

\section{MATERIALS AND METHODS}

Study site and sampling. The Zuari estuary located in Goa on the west coast of India is the terminus for a $>50 \mathrm{~km}$ long river that empties into the Arabian Sea. It is fringed by mangroves and referred to as a tidal plain estuary or a partially mixed estuary. The bottom topography is flat, with very few trenches as deep as $10 \mathrm{~m}$. The cross-sectional area of the estuary decreases exponentially. This decrease is more rapid in the first $20 \mathrm{~km}$ from the $5 \mathrm{~km}$ wide mouth. The amplitudes during spring tide and neap tide were 2.3 and $1 \mathrm{~m}$ respectively (Shetye \& Murty 1987).

The SW monsoon from June to September is characterized by heavy rainfall $(\sim 2500 \mathrm{~mm})$. The postmonsoon season, October to January, is dry and relatively cool, whereas the pre-monsoon from February to May is hot and humid. The characteristics of the Zuari estuary differ markedly between a low run-off season between November and May and a heavy run-off period of the southwest monsoon from June to September. From November to May the estuary is vertically mixed and the 2 processes controlling the transport of salt are (1) run-off-induced advective transport out of the estuary, and (2) tidally induced diffusive transport into the estuary. The magnitude of the latter is ca. $20 \%$ larger than the former, leading to a salinity rise in the estuary. The intrusion of salt water is seen as far as $65 \mathrm{~km}$ upstream in May, and reduced to a minimum of $20 \mathrm{~km}$ in June (Qasim \& Sen Gupta 1981). With the onset of the SW monsoon, the run-off increases dramatically and the estuary loses ca. $75 \%$ of its salt during the first 2 mo. Because the estuary is partially stratified from June to October, gravitational circulation is expected to play a role in addition to tidal diffusion and run off.

The sampling site was at $15^{\circ} 25.107^{\prime} \mathrm{N}$ and $73^{\circ} 51.472^{\prime} \mathrm{E}$ (Fig. 1). The average depth during the sampling months was approximately $4 \mathrm{~m}$. Strong changes in depth were not seen, as the change in mean sea level was only $10 \mathrm{~cm}$. Monthly water samples from the surface and from close to the bottom, i.e. just above the sediment layer, were collected at low tide in the mid reach of the estuary from October 1997 to September 1998. Samples were taken in acid-cleaned poly- 
propylene bottles after pre-filtration through $220 \mu \mathrm{m}$ mesh to remove larger plankton and processed in the laboratory within $2 \mathrm{~h}$ of sampling.

Physicochemical parameters. Water temperature, $\mathrm{pH}$ and salinity (AUTOSAL [8400 A]) were measured. Suspended particulate matter (SPM) was determined gravimetrically on pre-weighed GF/F (Whatman) filters as described by Krey (1964). After weighing, the filters were ignited at $450^{\circ} \mathrm{C}$ for $3 \mathrm{~h}$ and re-weighed after cooling in order to determine the particulate inorganic matter (PIM). Blank filters were also maintained to determine any weight changes. Particulate organic matter (POM) was calculated by subtracting PIM values from SPM. For the estimation of particulate organic carbon (POC) and particulate organic nitrogen (PON), the pre-filtered $(220 \mu \mathrm{m})$ water samples were filtered through pre-combusted GF/D (Whatman) filters and dried at $60^{\circ} \mathrm{C}$. After the filters were fumed with concentrated $\mathrm{HCl}$ for $24 \mathrm{~h}$ to remove carbonates (Hedges \& Stern 1984), they were analyzed using a Perkin Elmer Elemental CHN analyzer (Model 2400). The C:N ratio was estimated in a CHN analyzer after filtering water samples through GF/D $(\sim 3 \mu \mathrm{m})$ filters.

Size fractionation. The size distribution of particles in water samples was analyzed using a laser-based particle-size analyzer (Malvern 3600E). Sample dilution, if necessary, was performed with membrane $(0.22 \mu \mathrm{m})$-filtered $50 \%$ seawater under gentle magnetic stirring for $5 \mathrm{~min}$. For blanks, membrane $(0.22 \mu \mathrm{m})$-filtered seawater was used. For the gravimetric method, water samples were sequentially filtered through pre-weighed $3,2.7,1.2,0.7,0.45$ and $0.22 \mu \mathrm{m}$ pore-size polycarbonate filter (Millipore) under low vacuum $(<1 \mathrm{KPa})$. The filters were then rinsed with $200 \mathrm{ml}$ of membrane-filtered $(0.22 \mu \mathrm{m})$ distilled water, dried to constant weight at $40^{\circ} \mathrm{C}$ and weighed. The weights of the different size fractionated particles were expressed as percent of total particle weight. The total number of particles present in the water sample was counted using a Coulter counter (TAIL Model) and the numbers were expressed volumetrically.

Primary production. Primary production (PP) was measured by the $\mathrm{NaH}^{14} \mathrm{CO}_{3}$ assimilation method (Lohrenz et al. 1992). Light and dark acid-washed bottles (125 ml capacity) were filled with waters from the surface and close to the sediment. Samples were inoculated with $\mathrm{NaH}^{14} \mathrm{CO}_{3}$ (final activity: $5 \mu \mathrm{Ci} \mathrm{m}{ }^{-1}$, Bhabha Atomic Research Centre [BARC], Bombay) and deck-incubated. Neutral-density screens were employed. On retrieval, the water samples were filtered immediately through a $0.45 \mu \mathrm{m}$ filter (Millipore, GS type) under diffused light and low pumping pressure $(<13 \mathrm{KPa})$. Radiolabelled dissolved inorganic carbon was removed by exposing the filter papers to fumes of concentrated $\mathrm{HCl}$ for $1 \mathrm{~min}$. The filters were then placed in scintillation vials and $5 \mathrm{ml}$ of scintillation cocktail in dioxane (Spectrochem) were added. Radioactivity was measured in a liquid scintillation counter (LKB Wallac 1209). The estimated daily production rates were expressed as $\mu \mathrm{g} \mathrm{C}$ $\mathrm{m}^{-2} \mathrm{~d}^{-1}$.

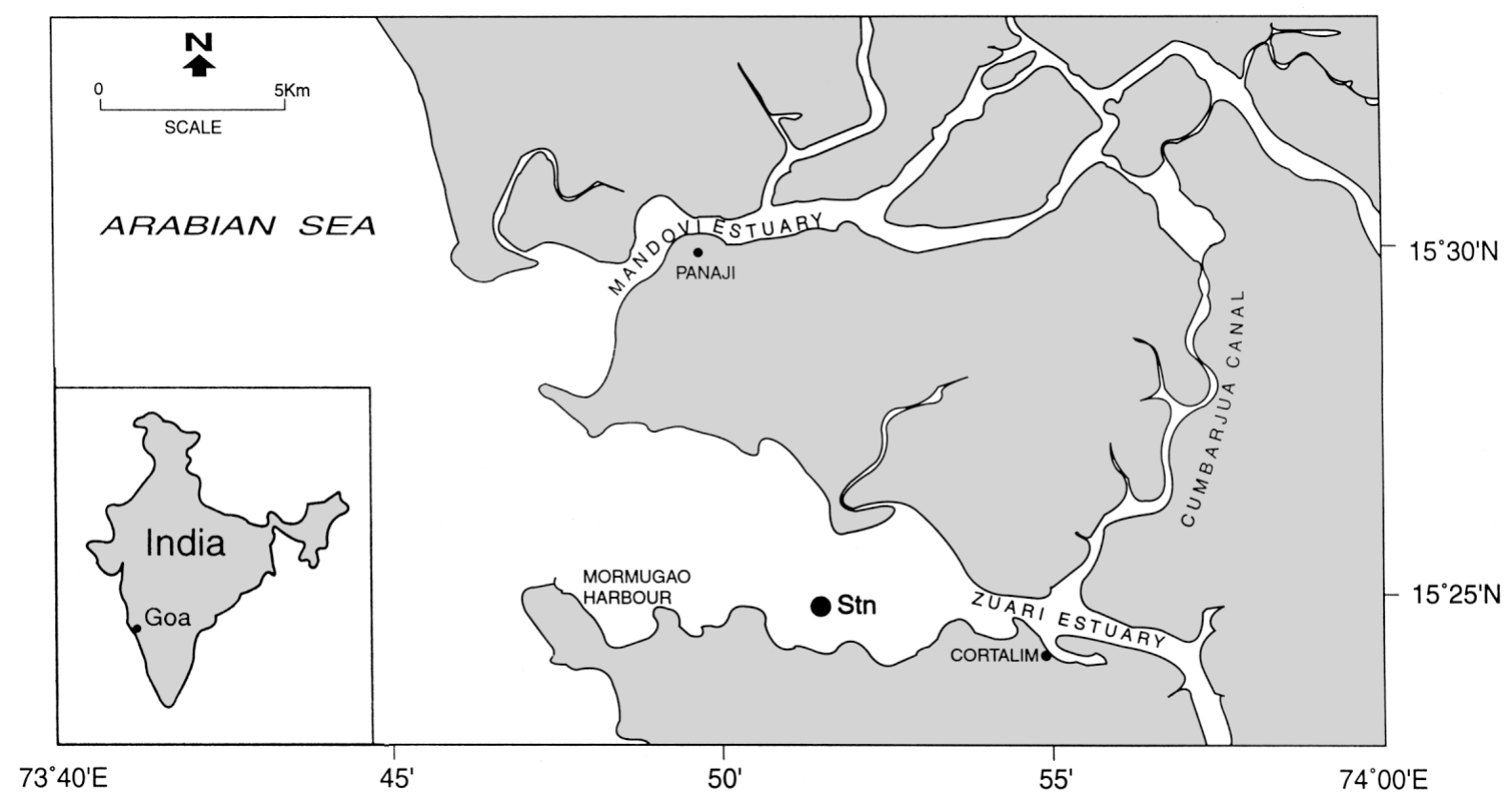

Fig. 1. Map showing the sampling site in Goa on the west coast of India 
Bacterial abundance and production. Sub-samples for bacterial abundance and ${ }^{3} \mathrm{H}$-thymidine incorporation were taken from the whole water samples and from a $3.0 \mu \mathrm{m}$ pore size pre-filtered (polycarbonate filter) water sample. The abundance and production of PAB were calculated as differences in the parameter between whole water samples and the $<3 \mu \mathrm{m}$ filtrates. To minimize cell damage and the possibility of forcing some large cells through the filter pores, fractionation was done at very low vacuum $(<1 \mathrm{kPa})$ and only a small filtration volume $(<100 \mathrm{ml})$ was used for each filter.

Bacterial numbers were estimated by the acridine orange direct count (AODC) method (Hobbie et al. 1977). Samples were preserved immediately with formaldehyde ( $2 \%$ final concentration). Known amounts of samples were filtered through $0.22 \mu \mathrm{m}$ black polycarbonate membrane filters (Nuclepore), stained with acridine orange $(0.01 \%)$ and enumerated using an epifluorescence microscope (BH-Olympus). Counting was done in triplicate with 20 fields counted for each sample, and bacterial numbers were expressed as number per litre.

Bacterial production (BP) was estimated by measuring the rate of [methyl ${ }^{3} \mathrm{H}$ ] thymidine incorporation (Fuhrman \& Azam 1980, 1982). Water samples (30 ml) were incubated for $1 \mathrm{~h}$ with ${ }^{3} \mathrm{H}$-thymidine (specific activity $=52 \mathrm{Ci} \mathrm{mM}^{-1}, \mathrm{BARC}$ ) at a final concentration of $10 \mathrm{nM}$. The reaction was terminated with $2 \%$ neutral buffered formalin. The samples were then filtered through $0.22 \mu \mathrm{m}$ polycarbonate filters (pre-soaked in 5\% TCA), extracted with cold $5 \%$ TCA and rinsed with ethanol. The dried filters were placed in scintillation vials with $3 \mathrm{ml}$ of dioxanebased scintillation cocktail (Sigma) and radio-assayed using a scintillation counter (Tri-CARB 2500 TR Packard). Thymidine incorporation rates were converted to bacterial carbon production (BCP) by using a thymidine conversion factor of $2.0 \times 10^{18}$ cells produced per mole of thymidine incorporated (Kirchman et al. 1982, Iriberri et al. 1990), and a carbon conversion factor of $2.0 \times 10^{-14} \mathrm{gC}$ cell $^{-1}$ (Lee \& Fuhrman 1987). Cell specific production/turnover rate was calculated by dividing the production rate by the bacterial abundance. Bacterial carbon demand (BCD) was calculated on the basis of bacterial carbon production by assuming a carbon assimilation efficiency of a minimum of 10 and a maximum of $30 \%$ (Bano et al. 1997), thus covering values found in most studies. BCD was also calculated based on the BGE values of our waters, which ranged from 10 to $26 \%$ (Ram et al. 2003).

Enzymatic profile. The ability of $\mathrm{PAB}$ to degrade polymers was studied based on their enzyme profile. Water samples $(200 \mathrm{ml})$ were filtered through a $3.0 \mu \mathrm{m}$ pore size polycarbonate (Millipore) filter. The filter was then transferred to a flask containing $200 \mathrm{ml}$ of sterile $50 \%$ seawater, to which $2.0 \mathrm{ml}$ of Tween 80 was added. The flask was kept on a shaker for 15 min and then sonicated for $10 \mathrm{~s}$ in order to reduce hydrophobic interactions (Yoon \& Rosson 1990) and to dislodge the bacteria from the particles. The suspension was then serially diluted with sterile $50 \%$ seawater. The diluted samples were surface plated on nutrient agar medium containing different substrates $(2 \% \mathrm{w} / \mathrm{v})$ for the enzymatic analysis of chitinase, deoxyribonuclease (Dnase), phosphatase, lipase, amylase and protease. The plates were incubated for $24 \mathrm{~h}$ at room temperature $\left(28 \pm 2^{\circ} \mathrm{C}\right)$. Positive colony forming units (CFU) were enumerated and the activity was expressed as the percentage of total colony forming units in each of the substrate.

\section{RESULTS}

\section{Water column characteristics}

The variation in temperature was minimal and ranged from 27 to $33^{\circ} \mathrm{C}$ (Table 1). The surface water salinity generally varied from 31 to 34 except during the SW monsoon period where a drastic decrease to 4 was noted. The SPM in the water column fluctuated from 2.6 to $729 \mathrm{mg} \mathrm{l}^{-1}$. The bottom waters recorded twice the SPM of the surface waters. The distribution of particulate organic matter showed the same trend. Size fractionation clearly showed that particles of the size range $>3$ to $<220 \mu \mathrm{m}$ (Fig. 2) were dominant throughout most of the study period at the surface and bottom waters. The number varied by 1 order of magnitude with the maximum recorded in the bottom waters during the pre-monsoon (February to May). Particle numbers showed a positive relationship with temperature $(r=0.71 ; p>0.01)$ and salinity $(r=0.84$; $\mathrm{p}>0.001)$ in the surface waters but not in the bottom waters (Table 2).

Table 1. Characteristics of the water column in the Zuari estuary

\begin{tabular}{|lcc|}
\hline Parameter & Surface & Bottom \\
\hline Temperature $\left({ }^{\circ} \mathrm{C}\right)$ & $27-33$ & $27-32$ \\
pH & $6-8$ & $6-8$ \\
Salinity & $4-34$ & $21-35$ \\
SPM $\left(\mathrm{mg} \mathrm{l}^{-1}\right)$ & $2.6-333$ & $3.4-729$ \\
POM $\left(\mathrm{mg} \mathrm{l}^{-1}\right)$ & $2.6-252$ & $3.4-546$ \\
PP $\left(\mu \mathrm{C} \mathrm{l}^{-1} \mathrm{~d}^{-1}\right)$ & $4.5-63$ & $1.2-25$ \\
Particle number $\left(\times 10^{9}^{-1}\right)$ & $0.8-2.8$ & $1.4-66$ \\
POC $\left(\mathrm{mg} \mathrm{C}^{-1}\right)$ & $0.5-18$ & $0.3-8$ \\
C:N ratio & $2.5-26$ & $3.8-93$ \\
\hline
\end{tabular}



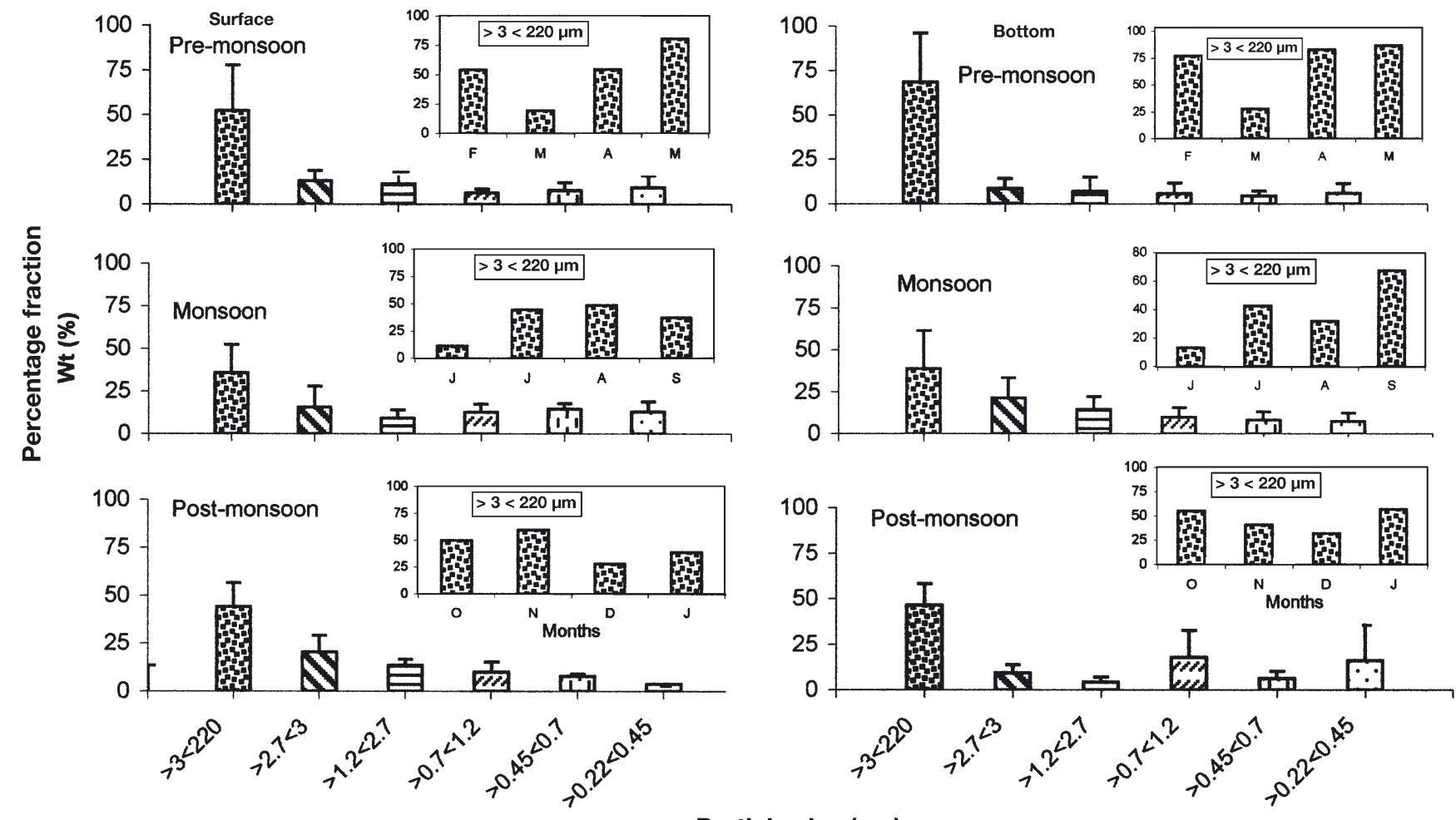

Particle size $(\mu \mathrm{m})$

Fig. 2. Seasonal distribution of particle sizes in the water column. Inset shows the monthly dominance of 3-220 $\mu \mathrm{m}$ particles. $y$-axis represents the wt (\%) of the respective particle size on the total particles

\section{Bacterial abundance}

The mean values of total PAB abundance of the surface waters was $4.06 \pm 2.35 \times 10^{9} \mathrm{l}^{-1}$ and that of the bottom waters was $8.65 \pm 10.49 \times 10^{9} \mathrm{l}^{-1}$. The average density of PAB was $48 \%$ of the total bacterial population, and sometimes reached up to $85 \%$ of the total population. As the SW monsoon set in, the bacterial density increased in both the surface and bottom waters, and it dropped towards the end of the season (Fig. 3A). The PAB abundance fluctuated seasonally with a maximum density during the post-monsoon period and a minimum during the pre-monsoon months (Fig. 3B). The annual variation in the $\mathrm{PAB}$ density of bottom waters was larger $(\mathrm{CV}=140)$ than the surface waters $(\mathrm{CV}=80)$. The percentage of isolates showing enzyme activity was also high in the bottom waters (Fig. 4). Of the measured environmental variables, temperature showed a negative correlation with $\mathrm{PAB}$ abundance. The abundance of PAB was limited by the abundance of total bacteria in the water as a linear relationship was observed throughout the study period for the surface $(\mathrm{r}=0.88 \mathrm{p}<$ $0.001)$ and bottom waters $(\mathrm{r}=0.98 \mathrm{p}<0.001)$ (Table 2).

\section{Bacterial production}

The rate of production of $\mathrm{PAB}$ varied between 11 and $328 \mu \mathrm{g} \mathrm{Cl}^{-1} \mathrm{~d}^{-1}$ at the surface while in the bottom waters it ranged from 1.3 to $109 \mu \mathrm{g} \mathrm{C} \mathrm{l}^{-1} \mathrm{~d}^{-1}$. The magnitude of
Table 2. Significant relationships between water variables and particleassociated bacteria (PAB) parameters. PP: primary productivity; TBA: total bacterial abundance; TBP: total bacterial production; ${ }^{*} \mathrm{p}>0.05 ;{ }^{* *} \mathrm{p}>0.01$; ${ }^{* * *} \mathrm{p}>0.001 ; \mathrm{df}=11$

\begin{tabular}{|lccccc|}
\hline Parameter & \multicolumn{2}{c}{ Particle number } & \multicolumn{2}{c|}{ PAB abundance } & \multicolumn{2}{c|}{ PAB production } \\
& Surface Bottom & Surface & Bottom & Surface Bottom \\
\hline Temperature & $0.71^{* *}$ & $-0.60^{*}$ & $-0.68^{*}$ & & \\
Salinity & $0.84^{* *}$ & & & & \\
PP & & $0.68^{* * *}$ & $0.98^{* * *}$ & & \\
TBA & & & & $0.99^{* * *}$ & $0.63^{*}$ \\
TBP & & & & & \\
\hline
\end{tabular}



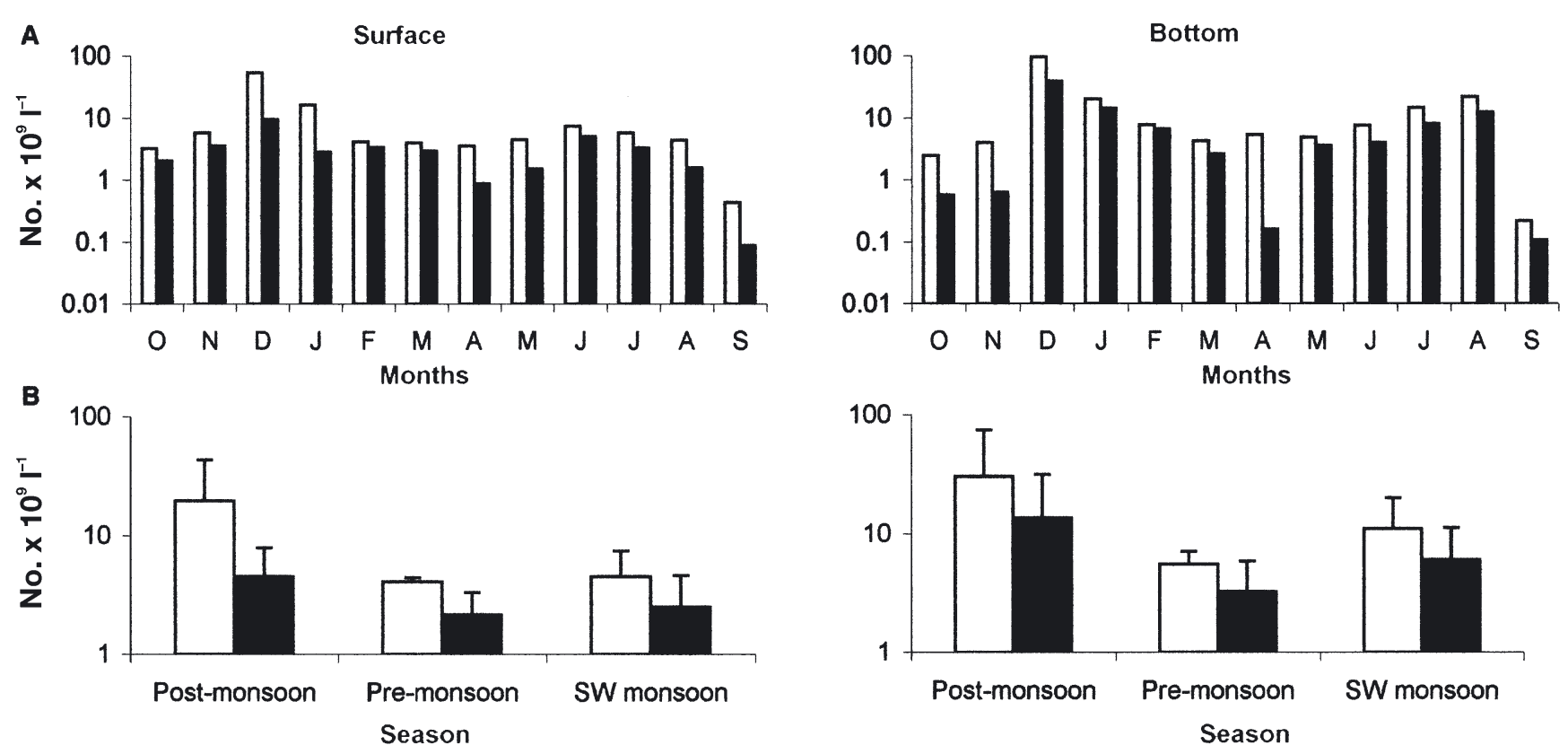

Fig. 3. (A) Monthly and (B) seasonal mean of 4 months variation along with standard deviation, in total and particle associated bacterial (PAB) counts in surface and bottom waters. ( $\square$ ) Total bacteria ( $\square$ ) PAB

variation was 30 times and in the surface waters and 84 times in the bottom waters. PAB contributed $\sim 60 \%$ of the total bacterial production (Fig. 5A). Like abundance of $\mathrm{PAB}$, productivity also showed temporal variation with the highest average productivity rate $\left(111 \mu \mathrm{g} \mathrm{Cl}^{-1} \mathrm{~d}^{-1}\right)$ in the surface waters during the monsoon season. In the bottom waters the average maximum production of $54 \mu \mathrm{g} \mathrm{Cl}^{-1} \mathrm{~d}^{-1}$ was recorded in the post-monsoon season (Fig. 5B). During the SW monsoon, the production was related to the particle numbers $(r=0.97 \mathrm{p}<0.01)$, which also showed a significant correlation with salinity $(\mathrm{r}=$ $0.84 \mathrm{p}>0.001$ ); such relationships were restricted to

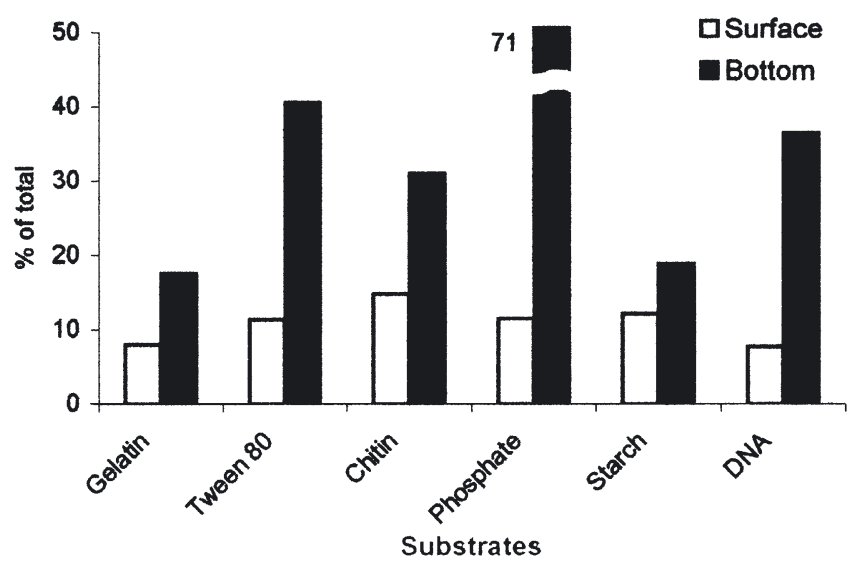

Fig. 4. Percentage of positive PAB on total number of bacteria (CFU) surface waters. The cell-specific production rate was highest during the SW monsoon season in the surface and bottom waters (Fig. 5C). The variation of cellspecific productivity was perhaps governed more by the production rates than by the PAB abundance, as no relationship was observed between PAB abundance and productivity. PAB carbon turnover rates ranged between 0.07 and $2.13 \mathrm{~h}$ in the surface waters and 0.2 and $18.5 \mathrm{~h}$ in the bottom waters. The variation in the $\mathrm{C}: \mathrm{N}$ ratio brought about $25 \%$ of the variation in PAB carbon turnover rates at the surface waters $(r=0.50)$. Though PAB production accounted for 1.1 to $294 \%$ of the PP at the station, it was not related to $\mathrm{PP}$. The BCD ranged from 380 to $990 \mathrm{mg} \mathrm{C} \mathrm{m}^{-2} \mathrm{~d}^{-1}$ when a maximum bacterial growth efficiency (BGE) value of 30 was used. The BCD ranged from 438 to $1142 \mathrm{mg} \mathrm{C} \mathrm{m}^{-2} \mathrm{~d}^{-1}$ when a BGE value of 26 was used. However, when a BGE of 10 was used values from 1140 to 2970 were obtained (Table 3). Ratios

Table 3. Seasonal variation in particle associated bacterial carbon demand (BCD), based on a bacterial growth efficiency (BGE) of 26 and $10 \%$, and primary production (PP). Values are depth integrated $\left(\mathrm{mg} \mathrm{C} \mathrm{m}^{-2} \mathrm{~d}^{-1}\right) .26$ and $10 \%$ are reported $\mathrm{BGE}$ values in the Zuari waters

\begin{tabular}{|lcrr|}
\hline Season & BCD (BGE of 26/10) & \multicolumn{1}{c}{ PP } & BCD/PP \\
\hline Pre-monsoon & $438 / 1140$ & 1022 & $0.4-1.1$ \\
SW monsoon & $1142 / 2970$ & 594 & $1.9-5.0$ \\
Post-monsoon & $842 / 2190$ & 717 & $1.2-3.1$ \\
\hline
\end{tabular}



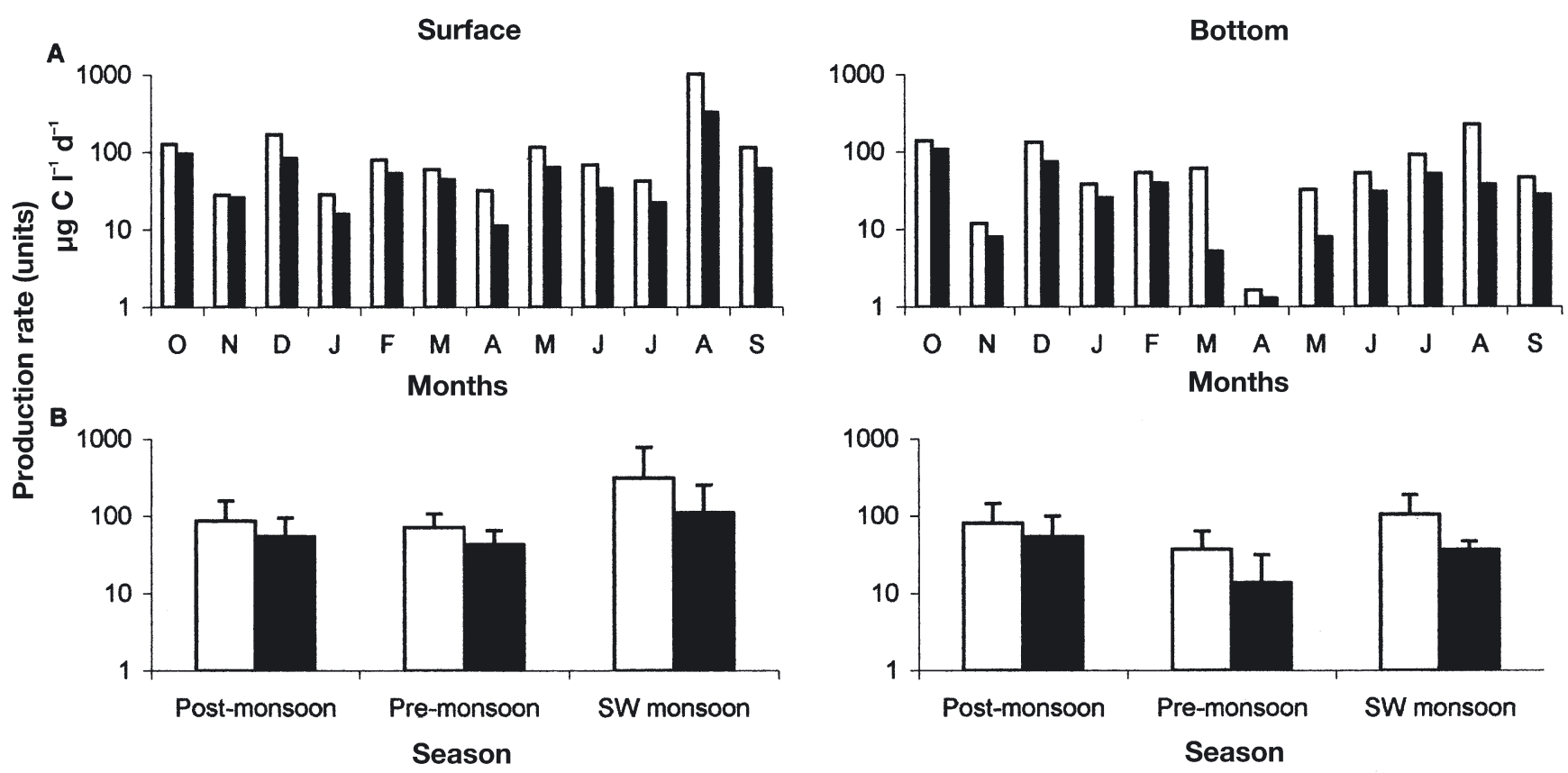

Fig. 5. (A) Monthly and (B) seasonal mean of 4 months variation along with standard deviation in total and particle-associated bacterial production (PABP) rates in surface and bottom waters. ( $\square$ ) Total bacteria ( $\square$ ) PABP

of depth integrated BCD and PP suggested that the estuarine system was autotrophic during the premonsoon season but shifted towards heterotrophy during the monsoon and post-monsoon seasons. A log productivity of $\mathrm{PAB}$ versus the log-biomass plot showed that the slope was almost parallel to the $x$-axis, suggesting top-down control (Fig. 6).

\section{DISCUSSION}

The nature of bacteria-particle associations has been the topic of sustained interest for many years (Bitton \& Marshall 1980, Wotton 1994, Murrell et al. 1999, Selje \& Simon 2003). Associated bacteria are usually found in low abundance $(10 \%)$ compared with free-living bacteria in most open aquatic ecosystems (Kirchman 1983, Simon 1987), although in some cases they reach up to 50 to $60 \%$ of the total biomass (Pedros Alio \& Brock 1983, Becquevort et al. 1998). Like many other estuarine ecosystems, the Zuari estuary exhibited a high load of suspended matter. Therefore, we separated the particle-associated bacteria by filtration through a $3 \mu \mathrm{m}$ filter as often used in other such studies (Kirchman \& Mitchell 1982, Simon 1985, Crump et al. 1998, Hollibaugh et al. 2000). The abundance of $\mathrm{PAB}$ in the Zuari estuary was higher than that of the free-living bacteria and at times accounted for $>80 \%$ of the total abundance, which was 2- to 5-fold higher than that reported in temperate waters (Cammen \&
Walker 1982, Berger et al. 1996) except in the Loire estuary (France). Similarly there was a large magnitude of variation in the bacterial abundance within the estuary compared to that in temperate estuaries (Ducklow 1982, Kondratiff \& Simmons 1985, Hoch et al. 1995). However, Crump et al. (1998) had observed variability in PAB every $2 \mathrm{~h}$ during a $28 \mathrm{~h}$ sampling series in the North Columbia River estuary.

In temperate estuaries, bacterial abundance seemed to be limited by one or more factors. Though Zuari estuary was influenced by the water from the adjacent areas as reflected in the variation in $\mathrm{pH}$, this variable did not influence the bacterial parameters, as no relationship was observed. In spite of salinity being a variable factor in the estuary, it did not have an influence on the variation in the abundance of bacteria (Table 2). Other factors that did not affect this variation in abundance were the inorganic nature of the particles (Hoch et al. 1995, Berger et al. 1996), high number of particles (Sanudo-Wilhelmy \& Taylor 1999) or input from mangroves (Bano et al. 1997). In this estuary none of the observed parameters were limiting bacterial abundance except temperature. Although temperature variation was not really strong, a negative relationship was observed. Usually a positive relationship is expected due to enhanced activity with an increase in temperature (Findlay et al. 1991b, Hoch \& Kirchman 1993). However, in the Humber estuary (northeast England) (Bent \& Goulder 1981) a negative relationship was due to increased suspended load brought about by influx of 

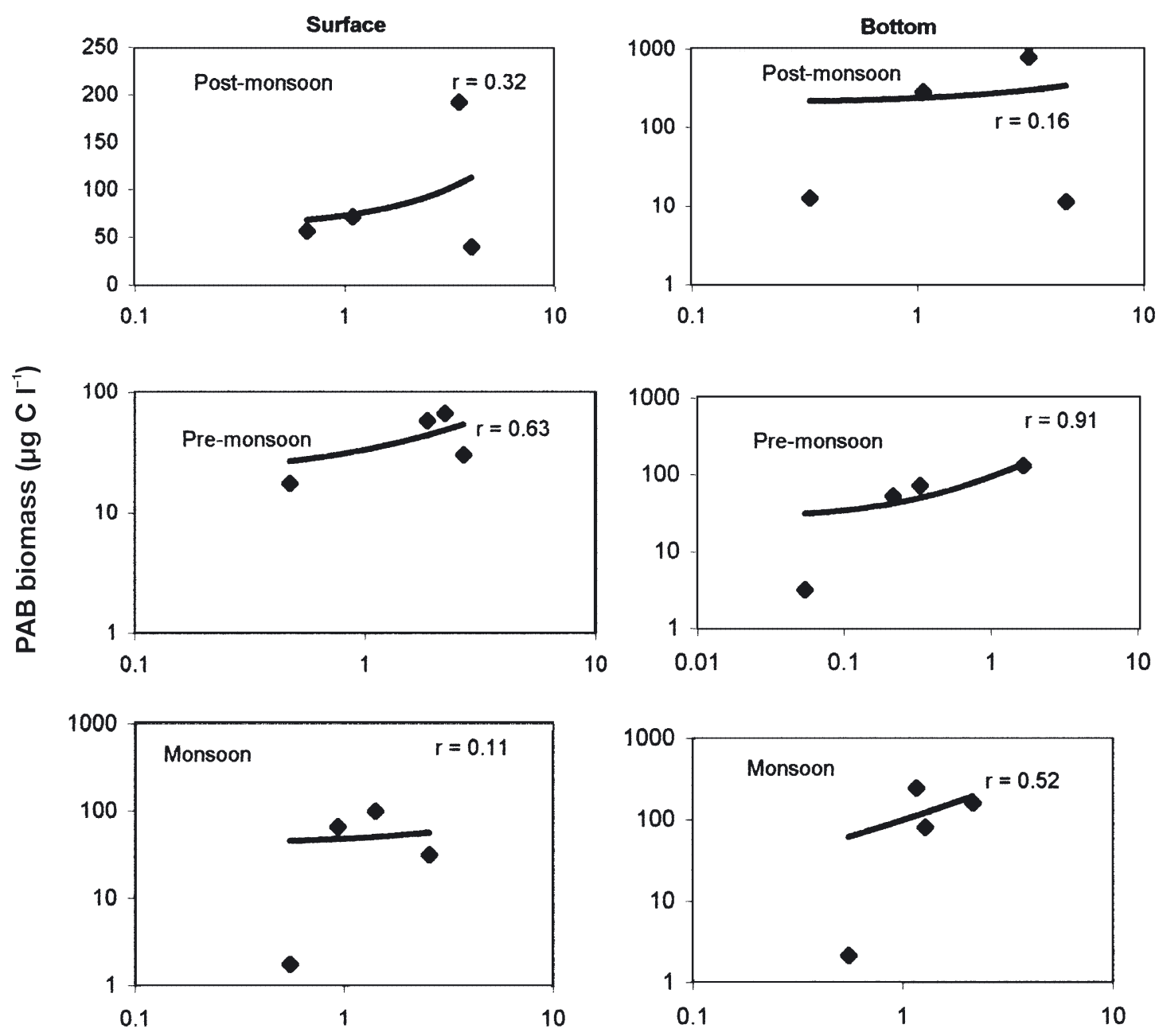

PAB production $\left(\mu \mathrm{C} \mathrm{C} \mathrm{I}^{-1} \mathrm{~h}^{-1}\right)$

Fig. 6. Relationship between bacterial biomass and production

freshwater. In this estuary, bacterial numbers were not related to suspended load or particle numbers, suggesting that factors other than the availability of colonization sites regulate the bacterial abundance on particles (Friedrich et al. 1999). Thus the negative relationship may be due to a combination of stronger changes in other variables like precipitation, winds and salinity. In our study, the observed organic content of the bottom waters was high, which may be due to the bottomresuspended clays bound with organic matter. Although organic carbon concentration is expected to correlate to bacterial activity, in our estuary the organic matter concentration was not related to the bacterial abundance. Murrell et al. (1999) suggested that standing crop measures of carbon was a poor predictor of bacterioplankton dynamics in San Francisco Bay (California, USA). Obviously, the nature of the organic matter rather than total organic matter is a more deci- sive variable (Bano et al. 1997), as the growth rate depends on the quality of the substrate (Zweifel et al. 1993). However, large variation is not unusual in aquatic regions (Iriberri et al. 1987) as the quality and quantity of the suspended particles determine the proportion of attached bacteria. Though the biochemical nature of the particles was not estimated in the present study, the C:N ratio showed a variation from 2 to 26 at the surface and from 4 to 93 at the bottom. It was inferred that during the SW monsoon, bacterial production on particles was the highest due to the input of utilizable organic matter with a low C:N ratio (mean: 4.7). This led to an increased growth rate of bacteria, as reported by Griffith et al. (1990) and Unanue et al. (1992). A high specific growth rate during the SW monsoon period supports our inference. The complex characteristics of the tropical estuary make it difficult to relate bacterial dynamics directly to its controlling factors. 
The rate of bacterial production in the present study was high, and such high bacterial production was observed in the Loire estuary, in the Ivory Coast, and in a tropical mangrove tidal creek of the Indus River delta (Ducklow \& Shiah 1993, Bano et al. 1997). The productivity of $\mathrm{PAB}$ in the present estuary was constant throughout the year as observed by Bano et al. (1997) in an Indus River delta creek (73 to $93 \%$ ). This high activity, in terms of productivity throughout the year, indicates that $\mathrm{PAB}$ contributed significantly to high secondary bacterial production of the estuary and was not under any stress. There is recent evidence that the estuarine bacterial community undergoes physiological stress leading to reduced bacterial production (del Giorgio \& Bouvier 2002), which was not observed at this station. However, during the pre-monsoon season, when the salinity values are the highest, the productivity rates are lower, especially in the bottom waters. In the temperate regions, unlike tropical estuaries, the magnitude varies from a low $7 \%$ in the Rhode River estuary (Rublee et al. 1984) to a very high $90 \%$ in the Columbia estuary (Crump et al. 1998). Seasonal changes in abundance and productivity have been reported in a variety of systems (Bent \& Goulder 1981, Rublee et al. 1984, Unanue et al. 1992, Crump \& Baross 1996, Sanudo-Wilhelmy \& Taylor 1999) although the timing, magnitude and the likely cause of the shift may differ. Lack of large variation in our waters may be due to the absence of marked temperature differences and seasonal planktonic blooms. Although there was no pronounced variation in abundance and productivity in this station, there was an increase in abundance and productivity from pre-monsoon, to monsoon, to postmonsoon. As mentioned earlier, the increase in bacterial numbers during the SW monsoon season was due to input of easily utilizable organic matter from terrestrial regions, or the re-suspension of organic matter from sediment to the water column. Freshwater flow has been shown to be a good proxy for organic carbon input, and this could in turn limit bacterioplankton abundance (Jassby et al. 1993). As the season progressed from the pre-monsoon period, the particles could tend to become organically less labile with a concomitant increase in hydrolytic enzymatic activities during the SW and post monsoon. The temporal variation in the enzymatic profile reflected the change in nature of the particles as the season progressed. The particles get colonized in subsequent periods and may go through a high succession of sequential colonisations similar to that observed in phytoplankton detritus (Biddanda \& Pomeroy 1988, Murrell et al. 1999). In line with previous reports (Crump et al. 1998, Selje \& Simon 2003), PAB in the Zuari estuary is involved in the decomposition processes, as they have high hydrolytic enzymatic activities (Smith et al. 1992,
Hoppe et al. 1993). In accordance with earlier findings, PAB was metabolically active as a higher biomass-specific bacterial production was observed in comparison with free-living bacteria (Kirchman \& Mitchell 1982, Pedros-Alio \& Brock 1983, Worm \& Sondergaard 1998), which are small, inactive and in a dormant state (Jürgens \& Güde 1994).

Although the bacterial production was high during the SW monsoon months, the bacterial standing stock was non-parallel to the production rate in the estuary. Such a scenario has been reported from other estuaries (Findlay et al. 1991a, Wehr et al. 1998). The population of bacteria in an ecosystem is controlled mainly by either substrate availability (bottom-up control) or by grazers (top-down). As the growth rate of PAB was higher than the unattached bacteria in both lacustrine and marine realms (Crump et al. 1998), their size was larger than the free-living bacteria (Goosen et al. 1995), hence they may be under grazing pressure. Although ingestion by grazers per se was not measured in the present study, the rate of bacterial production and the standing stock reflected the grazing pressure on these groups of bacteria. This is further evidenced indirectly by the decreased slope of regression of log biomass versus log production. If bacterioplankton were controlled only by substrate availability, the slope of regression would be near or equal to 1 . Ducklow (1992) has theoretically defined that a slope of $>0.6$ would correspond to a strong effect, $0.4-0.6$ to an intermediate effect, $<0.4$ to a weak effect, and $<0.2$ to no effect of substrate control. In our study the relationship was ca. 0.4, which is intermediate, indirectly suggesting both substrate control (bottom-up) and a possibility of top-down control (Fig. 6). Thus, depending on the time of collection, PAB of this estuary seems to be controlled either by bacterivores (Fuhrman \& Noble 1995) or substrate availability. The role of viruses, however, has not been examined in this study but is assumed to be significant.

As PAB abundance and production formed a significant portion of the microbial biomass in the Zuari waters, the BCD would be expected to be high. The reported $B G E$ from marine system ranged from $<10$ to $50 \%$ (Azam et al. 1983, del Giorgio et al. 1997). The average BGE value in our waters was $18( \pm 7.84 \%)$, (Ram et al. 2003). If we take the lowest and highest values for BGE, the carbon from PP (assuming 10\% exudates) was not sufficient to meet the BCD, except during the pre-monsoon season. Hence it is suggested that the excess carbon requirement was met from allochthonous sources as reported by Bano et al. (1997).

Estuaries are usually net-heterotrophic as the bacterial production at certain times exceeds contemporaneous primary production (Findlay et al. 1991b) be- 
cause of a high load of particulate and dissolved organic matter (Findlay et al. 1991b, Goosen et al. 1997). Heterotrophy in our study occurs when phototrophic carbon fixation is lower than BCD regardless of zooplankton requirement. The station changes temporally from an autotrophic system during the premonsoon to a heterotrophic system during the monsoon and post-monsoon seasons. Unlike turbid estuaries such as the Elbe, Westerschelde and Gironde (Germany, Netherlands and France, respectively) where heterotrophic status is achieved throughout the year (Goosen et al. 1999), in this estuary there was a shift in status. A spatial shift in status from upstream to down stream was observed in the Schelde estuary (Goosen et al. 1997). In conclusion, our study demonstrates that (1) in the tropical Zuari estuary PAB dominate bacterial processes and contributed significantly to the total secondary production, (2) the abundance of bacteria was not markedly influenced by the environmental variables, but by the availability of substrate and grazers, and (3) the bacterial carbon demand was supported by allochthonous carbon input.

Acknowledgements. This work was sponsored by the Office of Naval Research, Washington, DC, USA. Primary production data was collected by Dr. Krishna Kumari, scientist at the National Institute of Oceanography, Goa. The authors wish to thank Prof. K. Banse, University of Seattle, USA and the anonymous referees for their useful comments, which improved the manuscript. This is NIO Contribution No. 3827.

\section{LITERATURE CITED}

Alldredge AL, Silver M (1988) Characteristics, dynamics and significance of marine snow. Prog Oceanogr 20:41-58

Azam F, Fenchel T, Field JG, Gray JS, Meyer-Reil LA, Thingstad $F$ (1983) The ecological role of water column microbes in the sea. Mar Ecol Prog Ser 10:257-263

Bano N, Nisa MU, Khan N, Saleem M, Harrison PJ, Ahmed SI, Azam F (1997) Significance of bacteria in the flux of organic matter in the tidal creeks of the mangrove ecosystem of the Indus River delta, Pakistan. Mar Ecol Prog Ser 157:1-12

Becquevort S, Rousseau V, Lancelot C (1998) Major and comparable roles for free-living and attached bacteria in the degradation of Phaeocystis-derived organic matter in Belgian coastal waters of the North Sea. Aquat Microb Ecol 14:39-48

Bell CR, Albright LJ (1981) Attached and free-floating bacteria in the Fraser River estuary, British Columbia, Canada. Mar Ecol Prog Ser 6:317-327

Bent EJ, Goulder R (1981) Planktonic bacteria in the Humber Estuary: seasonal variation in population density and heterotrophic activity. Mar Biol 62:35-45

Berger B, Hoch B, Kavka G, Herndl G (1996) Bacterial colonization of suspended solids in the River Danube. Aquat Microb Ecol 10:37-44

Biddanda BA, Pomeroy LR (1988) Microbial aggregation and degradation of phytoplankton-derived detritus in seawater. I. Microbial succession. Mar Ecol Prog Ser 42:79-88
Bitton G, Marshall KC (eds) (1980) Adsorption of microorganisms to surfaces. Wiley-Interscience, New York

Cammen LM, Walker JA (1982) Distribution and activity of associated and free-living suspended bacteria in the Bay of Fundy. Can J Fish Aquat Sci 39:1655-1663

Caron DA (1987) Grazing of attached bacteria by heterotrophic microflagellates. Microb Ecol 13:203-218

Caron DA, Davis PG, Madin LP, Sieburth JM (1986) Enrichment of microbial populations in macroaggregates (marine snow) from surface waters of the North Atlantic. J Mar Res 44:543-565

Crump BC, Baross JA (1996) Particle-attached bacteria and heterotrophic plankton associated with the Columbia River estuarine turbidity maxima. Mar Ecol Prog Ser 138: 265-273

Crump BC, Baros JA, Simenstad CA (1998) Dominance of particle-attached bacteria in the Columbia River estuary, USA. Aquat Microb Ecol 14:7-18

Crump BC, Armbrust EV, Baross JA (1999) Phylogenetic analysis of particle-attached and free-living bacterial communities in the Columbia River, its estuary, and the adjacent coastal ocean. Appl Environ Microbiol 65:3192-3204

del Giorgio PA, Bouvier TC (2002) Linking the physiological and phylogenetic succession in free-living bacterial communities along an estuarine salinity gradient. Limnol Oceanogr 47:471-486

del Giorgio PA, Cole JJ, Cimbleris A (1997) Respiration rates in bacteria exceed phytoplankton production in unproductive aquatic systems. Nature 385:148-151

Ducklow HW (1982) Chesapeake Bay nutrient and planktonic dynamics. 1. Bacterial biomass and production during spring tidal destratification in the York River, Virginia estuary. Limnol Oceanogr 27:651-659

Ducklow HW (1992) Factors regulating bottom-up control of bacteria biomass in open ocean plankton communities. Arch Hydrobiol Beih 37:207-217

Ducklow HW, Shiah FK (1993) Bacterial production in estuaries. In: Ford TG (ed) Aquatic microbiology: an ecological approach. Blackwell Scientific Publications, Boston, p 261-287

Eisma D (1993) Flocculation and de-flocculation of suspended matter in estuaries. Arch Hydrobiol Suppl 75:311-324

Findlay S, Pace M, Lints D (1991a) Variability and transport of suspended sediment, particulate and dissolved organic carbon in the tidal freshwater Hudson River. Biogeochem 12:149-169

Findlay S, Pace ML, Lints D, Cole JJ, Caraco NF, Peierls B (1991b) Weak coupling of bacterial and algal production in a heterotrophic ecosystem: the Hudson River estuary. Limnol Oceanogr 36:268-278

Fletcher M (1991) The physiological activity of bacteria attached to solid surfaces. Adv Microb Physiol 32:53-85

Friedrich U, Schallenberg M, Holliger C (1999) Pelagic bacteria-particle interactions and community-specific growth rates in four lakes along a trophic gradient. Microb Ecol 37:49-61

Fuhrman JA, Azam F (1980) Bacterioplankton secondary production estimates for coastal waters of British Columbia, Antarctica and California. Appl Environ Microbiol 39: 1085-1095

Fuhrman JA, Azam F (1982) Thymidine incorporation as a measure of heterotrophic bacterioplankton production in marine surface. Mar Biol 66:109-120

Fuhrman JA, Noble RT (1995) Viruses and protists cause similar bacterial mortality in coastal seawater. Limnol Oceanogr 40:1236-1242

Goosen NK, van-Rijswijk P, Brockmann U (1995) Comparison 
of heterotrophic bacterial rates in early spring in the turbid estuaries of the Scheldt and the Elbe. Hydrobiologia 311: $31-42$

Goosen NK, van-Rijswijk P, Kromkamp J, Peene J (1997) Regulation of annual variation in heterotrophic bacterial production in the Schelde Estuary (SW Netherlands). Aquat Microb Ecol 12:223-232

Goosen NK, Kromkamp J, Peene J, van-Rijswijk P, vanBreugel P (1999) Bacterial and phytoplankton production in the maximum turbidity zone of three European estuaries: the Elbe, Westerschelde and Gironde. Special Issue: Biogeochemistry of the maximum turbidity zone of estuaries. J Mar Syst 22:151-171

Griffith PC, Douglas DJ, Wainright SC (1990) Metabolic activity of size-fractionated microbial plankton in estuarine, nearshore and continental shelf waters of Georgia. Mar Ecol Prog Ser 108:1-10

Grossart HP, Simon M (1998) Bacterial colonization and microbial decomposition of limnetic organic aggregates (lake snow). Aquat Microb Ecol 15:127-140

Healey MJ, Moll RA, Diallo CO (1988) Abundance and distribution of bacterioplankton in the Gambia River, West Africa. Microb Ecol 16:291-310

Hedges JI, Stern JH (1984) Carbon and nitrogen determinations of carbonate-containing solids. Limnol Oceanogr 29: $657-663$

Hobbie JE, Daley RJ, Jasper S (1977) Use of Nuclepore filters for counting bacteria by fluorescence microscopy. Appl Environ Microbiol 33:1225-1228

Hoch BM, Berger B, Kavka G, Herndl GJ (1995) Remineralization of organic matter and degradation of the organic fraction of suspended solids in the River Danube. Aquat Microb Ecol 9:279-288

Hoch MP, Kirchman DL (1993) Seasonal and inter-annual variability in bacterial production in a temperate estuary. Mar Ecol Prog Ser 98:283-295

Hollibaugh JT, Wong PS, Murrell MC (2000) Similarity of particle-associated and free-living bacterial communities in Northern San Francisco Bay, California. Aquat Microb Ecol 21:103-114

Hoppe HG, Ducklow HW, Karrasch B (1993) Evidence for dependency of bacterial growth on enzymatic hydrolysis of particulate organic matter in the mesopelagic ocean. Mar Ecol Prog Ser 93:277-283

Iriberri J, Unanue M, Barcina I, Egia L (1987) Seasonal variation in population density and heterotrophic activity of attached and free-living bacteria in coastal waters. Appl Environ Microbiol 53:2308-2314

Iriberri J, Unanue M, Ayo B, Barcina I, Egea L (1990) Bacterial production and growth rate estimation from (super $(3) \mathrm{H})$ thymidine incorporation for attached and free-living bacteria in aquatic systems. Appl Environ Microbiol 56: 483-487

Jassby AD, Cloern JE, Powell TM (1993) Organic carbon sources and sinks in San Francisco Bay: variability induced by river flow. Mar Ecol Prog Ser 95:39-54

Jürgens K, Güde H (1994) The potential importance of grazing-resistant bacteria in planktonic systems. Mar Ecol Prog Ser 112:169-188

Kiørboe T, Andersen KP, Dam HG (1990) Coagulation efficiency and aggregate formation in marine phytoplankton. Mar Biol 107:135-145

Kirchman D (1983) The production of bacteria attached to particles suspended in a freshwater pond. Limnol Oceanogr 28:858-872

Kirchman DL (1993) Particulate detritus and bacteria in marine environments. In: Ford TE (ed) Aquatic microbiol- ogy-an ecological approach. Blackwell, Oxford, p 321-341

Kirchman D, Mitchell R (1982) Contribution of particle bound bacteria to total microheterotrophic activity in five ponds and two marshes. Appl Environ Microbiol 43:200-209

Kirchman DL, Ducklow H, Mitchell R (1982) Estimation of bacterial growth from changes in uptake rates and biomass. Appl Environ Microbiol 44:1296-1307

Kondratieff PF, Simmons GM Jr (1985) Microbial colonization of seston and free bacteria in an impound river. Hydrobiologia 128:127-133

Krey I (1964) Die mittlere Tiefenverteilung von Seston Mikrobiomasse und Detritus in nordlichen Nordatlantik. Kiel Meeresforsch 20:18-29

Lee C, Wakeham S (1988) Organic matter in seawater: biogeochemical process. In: Chemical oceanography, v. 9 . Academic Press, London, p 1-51

Lee S, Fuhrman JA (1987) Relationships between biovolume and biomass of naturally derived marine bacterioplankton. Appl Environ Microbiol 53:298-1303

Lochte K (1991) Protozoa as makers and breakers of marine aggregates. In: Reid PC, Turley CM, Burkill PH (eds) Protozoa and their role in marine processes. Springer-Verlag, Berlin, p 327-346

Lohrenz SE, Wiesenburg DA, Rein CR, Arnone RA, Taylor CD, Knauer GA, Knap AHA (1992) A comparison of in situ and simulated in situ methods for estimating oceanic primary production. J Plankton Res 14:201-221

Müller-Niklas G, Schuster S, Kaltenbock E, Herndl GJ (1994) Organic content and bacterial metabolism in amorphous aggregations of the northern Adriatic Sea. Limnol Oceanogr 31:420-426

Murrell MC, Hollibaugh JT, Silver MW, Wong PS (1999) Bacterioplankton dynamics in northern San Francisco Bay: role of particle association and seasonal freshwater flow. Limnol Oceanogr 44:295-308

Painchaud JD, Therriault JC (1989) Relationships between bacteria, phytoplankton and particulate organic carbon in the upper St. Lawrence estuary. Mar Ecol Prog Ser 56: 301-311

Pedros-Alio C, Brock TD (1983) The importance of attachment to particles for planktonic bacteria. Arch Hydrobiol 98:354-379

Qasim SZ, Sen Gupta R (1981) Environmental characteristics of the Mandovi-Zuari estuarine system in Goa. Estuar Coast Shelf Sci 13:557-578

Ram ASP, Nair S, Chandramohan D (2003) Bacterial growth efficiency in the tropical estuarine and coastal waters of Goa, southwest coast of India. Microb Ecol 45:88-96

Rublee PA, Merkel SM, Faust MA, Miklas J (1984) Distribution and activity of bacteria in the headwaters of the Rhode River Estuary, Maryland, USA. Microb Ecol 10: 243-255

Sanudo-Wilhelmy SA, Taylor GT (1999) Bacterioplankton dynamics and organic carbon partitioning in the lower Hudson River estuary. Mar Ecol Prog Ser 182:17-27

Selje N, Simon M (2003) Composition and dynamics of particle-associated and free-living bacterial communities in the Weser estuary, Germany. Aquat Microb Ecol 30:221-237

Shetye SR, Murty CS (1987) Seasonal variation of the salinity in the Zuari estuary, Goa, India. Proc Indian Acad Sci Earth Planet Sci 96:249-257

Shetye SR, Gouveia AD, Singbal SY, Naik CG, Sundar D, Michael GS, Nampoothiri G (1995) Propagation of tides in the Mandovi-Zuari estuarine network. Proc Indian Acad Sci Earth Planet Sci 104:667-682

Simon M (1985) Specific uptake rates of amino acids by 
attached and free-living bacteria in a mesotrophic lake. Appl Environ Microbiol 49:1254-1259

Simon M (1987) Biomass and production of small and large free-living and attached bacteria in Lake Constance. Limnol Oceanogr 32:591-607

Smith DC, Simon M, Alldredge AL, Azam F (1992) Intense hydrolytic enzyme activity on marine aggregates and implications for rapid particle dissolution. Nature 359: 139-142

Turley CM, Mackie PJ (1994) The biogeochemical significance of attached and free-living bacteria and the flux of particles in the deep north-eastern Atlantic Ocean. Mar Ecol Prog Ser 115:191-203

Unanue M, Aya B, Azua I, Barcina I, Iriberri J (1992) Temporal variabiltity of attached and free-living bacteria in coastal waters. Microb Ecol 23:27-39

Velmirov B (1991) Detritus and the concept of non-predatory loss. Arch Hydrobiol 121:1-22

Wehr JD, Hole DA, Macdonald MM, Lonergran SP (1998) Effects of different organic carbon sources on a freshwater

Editorial responsibility: Karin Lochte,

Kiel, Germany plankton community. Can J Aquat Sci 5:2150-2160

Worm J, Sondergaard M (1998) Dynamics of heterotrophic bacteria attached to Microcystis spp. (Cyanobacteria). Aquat Microb Ecol 14:19-28

Wotton RS (ed) (1994) The biology of particles in aquatic systems, 2nd edn. Lewis Publishers, Boca Raton, FL

Yoon WB, Rosson R (1990) Improved method of enumeration of attached bacteria for study of fluctuation in the abundance of attached bacteria and free-living bacteria in response to diel variation in a seawater turbidity. Appl Environ Microbiol 56:595-600

Zimmermann $\mathrm{H}$ (1997) The microbial community on aggregates in the Elbe estuary. Aquat Microb Ecol 13: $37-46$

Zimmermann H, Kausch H (1996) Microaggregates in the Elbe estuary: structure and colonization during spring. Arch Hydrobiol (Spec Issue) Adv Limnol 48:85-92

Zweifel UL, Norrman B, Hagstrom A (1993) Consumption of dissolved organic carbon by marine bacteria and demand for inorganic nutrients. Mar Ecol Prog Ser 101:23-32

Submitted: December 28, 2002; Accepted: May 5, 2003

Proofs received from author(s): August 4, 2003 